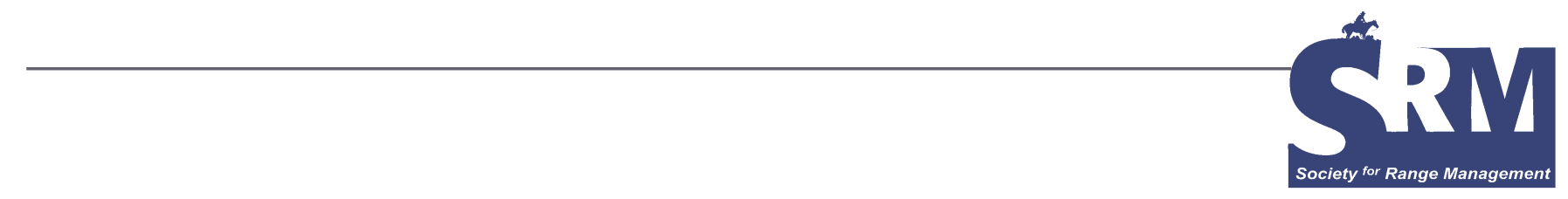

\title{
Western Ranching, Trade Policies, and Peak Oil
}

\section{Skyrocketing trade deficits coupled with depletion of oil and natural gas reserves could make rangeland livestock production essential to food security in the United States.}

\section{By Jerry L. Holechek and Jerry Hawkes}

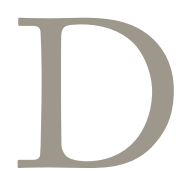

uring the past 12 years ranchers in the western United States have confronted great change and hard times. In New Mexico, where we live, annual surveys by range economists at New Mexico State University show that, as a group, ranchers have been steadily losing money since 1994 (Table 1). Even though there has been a gradual upward trend in cattle prices since 1996, extended drought and rising costs have kept most ranches financially in the red. Other segments of agriculture in the United States have also confronted a profit squeeze due to inadequate prices and rising costs. This is in contrast to the American and world economy, which have experienced an extended boom since 1991, interrupted by only a brief and mild slowdown in 2001 and 2002. It would seem that improved world economic conditions, coupled with rising world human populations (about $\left.1.2 \% \cdot y^{-1}\right)$ and nationally $\left(1 \% \cdot y^{-1}\right)$ would benefit America's farmers and ranchers. However, this has not been the case. Lack of profitability has undoubtedly been a critical factor in the unprecedented conversion of western ranches into other uses. ${ }^{1}$

We have read several articles and books by economic and natural resource experts that have caused us to conclude that world trade policies and rising energy costs have been important factors explaining the plight of ranchers since the early 1990s. Much has changed since we last addressed macro-economic factors affecting ranchers. ${ }^{2}$ Therefore, in this article we will again examine how global conditions relating to trade and energy are affecting western ranchers. In addition we will provide insight into future challenges and opportunities confronting western ranchers.

\section{A Modern World Trade Policies History}

In order to develop this discussion we have drawn heavily on 4 recent books by respected economists that comprehensively explain current world trade policies. ${ }^{3-6}$ These economists make it clear that basic knowledge of monetary policy by the United States government is essential in understanding globalization and modern world trade. We will summarize these discussions on this subject.

During most of its history, the United States government closely tied the supply dollars to reserves of gold. ${ }^{4}$ Immediately following World War II in 1946, the major trading countries of the world reached an accord (the Bretton Woods Agreement) that United States dollars would serve as the basic monetary unit of exchange for international trade. Any country holding dollars could readily acquire or exchange them for gold with the US government at the rate of 32 dollars per ounce of gold. The Bretton Woods Agreement basically gave the United States control of the free world's money supply. From the late 1940s into the early 1960s, the United States accumulated large gold reserves as it was the world's largest manufacturing economy and exporter of products. By the second half of the 1960s, the rebuilding of the Japanese and European economies, the proliferation 


\begin{tabular}{|l|c|}
\hline $\begin{array}{l}\text { Table 1. Net returns } \\
\text { ranches, 1986-2004* }\end{array}$ & New for New Mexico \\
\hline Year & 50.30 \\
\hline 1986 & 104.30 \\
\hline 1987 & 95.55 \\
\hline 1989 & 78.97 \\
\hline 1991 & 77.40 \\
\hline 1992 & 76.61 \\
\hline 1993 & 61.93 \\
\hline 1994 & 9.32 \\
\hline 1995 & -41.62 \\
\hline 1996 & -14.00 \\
\hline 1997 & 22.55 \\
\hline 1998 & 31.94 \\
\hline 1999 & 25.85 \\
\hline 2000 & -3.99 \\
\hline 2001 & -6.21 \\
\hline 2002 & Net \\
\hline 2003 & \\
\hline 2004 & \\
\hline
\end{tabular}

*Source: Data from New Mexico State University Agricultural Experiment Station reports prepared by Dr. Jerry Hawkes, range economist, New Mexico State University.

of social programs in the United States, and the high costs of the Vietnam war caused rapid buildup in the number of dollars in foreign lands. Foreign governments began exchanging their dollars for gold at the US Federal Reserve. Initially there was little concern, but by 1970, the flow of gold from Fort Knox had become a torrent. In August of 1971, President Nixon suspended the convertibility of dollars into gold. After failed attempts to revise the Bretton Woods system, the major trading powers agreed to allow their currencies to float freely against one another. However, the dollar remained as the world's primary monetary unit. Because currencies were no longer tied to the finite supply of gold, but rather to US dollars, various governments, including the United States, could and did increase their currencies at will. This allowed US government budget deficits to drastically increase and trade deficits with other nations to become chronic and reach enormous levels.

Without the monetary discipline (gold-backed dollars) of the Bretton Woods Agreement, the United States has gone from the world's largest creditor to the world's largest debtor. ${ }^{3,4,6}$ Total foreign debt owed by the United States has skyrocketed from 350 billion dollars in 1980 to nearly 6 trillion dollars in 2007. Annual trade deficits are rapidly increasing and will be over 800 billion dollars in 2006 (Table 2).

The United States, which is the world's largest economy, has become the world's engine of economic growth because it now imports over $80 \%$ more products on a dollar-valued basis than it exports to the rest of the world (Table 2). Basically, the health of the world economy depends on the United States constantly increasing its level of indebtedness. However, recently retired Federal Reserve Chairman, Alan Greenspan, has publicly stated he believes the large trade deficits of the United States are unsustainable. Several other economists have reached this same conclusion. ${ }^{3,4,6}$

Essentially the change from a gold to a dollar standard in 1973 lead to the age of globalization by allowing the United States to buy massive amounts of products from the rest of the world through provision of nothing more than paper dollars. This has benefited US consumers by providing them with cheap goods, services, and food from developing countries that have comparatively low-cost labor and minimal environmental regulation. Interest rates have been kept low because the abundance of cheap goods has put downward pressure on consumer prices, and hence interest rates. Another important factor causing low interest rates during the past 15 years is that foreign countries with large trade surpluses with the United States have heavily invested their dollars back into US assets, particularly treasury bonds. Foreigners now hold $40 \%$ of US government debt. ${ }^{3,46}$ Basically, expanding trade deficits have meant that foreigners hold more and more claims on US assets and production. Ultimately this could lead to a declining standard of living and impoverishment of US citizens. . $^{3,4,6}$

In order to have balanced trade, the value of the dollar will have to fall by $30 \%$ to $80 \%$ against various other foreign currencies, and various tariffs and other trade restrictions will be needed to slow the inflow of foreign goods, services, and agricultural products. This change of policy is unattractive to American politicians and most of the public because on a short term basis it would cause a rapid rise in interest rates and prices of most goods, foods, and services. ${ }^{3-6}$

Generally the primary trading partners with the United States (China, Japan, Canada, Mexico, Brazil) have favored a strong dollar relative to their own currencies. This allows them to have large trade surpluses essential for rapid economic growth in their countries. Whenever the dollar 
Table 2. United States exports, imports, and merchandise trade balances in billions of dollars (19912005)*

\begin{tabular}{|c|c|c|c|}
\hline \multirow[b]{2}{*}{ Year } & \multicolumn{3}{|c|}{ Billions of Dollars } \\
\hline & Exports & Imports & Trade Balance \\
\hline 1991 & 414 & 491 & -77 \\
\hline 1992 & 440 & 536 & -96 \\
\hline 1993 & 457 & 589 & -132 \\
\hline 1994 & 503 & 669 & -166 \\
\hline 1995 & 575 & 749 & -174 \\
\hline 1996 & 612 & 803 & -191 \\
\hline 1997 & 678 & 876 & -198 \\
\hline 1998 & 670 & 917 & -247 \\
\hline 1999 & 684 & 1,030 & -346 \\
\hline 2000 & 772 & 1,224 & -452 \\
\hline 2001 & 719 & 1,146 & -427 \\
\hline 2002 & 682 & 1,165 & -483 \\
\hline 2003 & 713 & 1,260 & -547 \\
\hline 2004 & 808 & 1,473 & -665 \\
\hline 2005 & 895 & 1,667 & -783 \\
\hline
\end{tabular}

*Source: US Department of Commerce, Bureau of Economic Analysis, US International Transaction Data.

has started to fall against particular foreign currencies, the central banks in these individual countries have purchased dollars to depreciate their own currencies and then invested the dollars into US assets and treasury bonds. ${ }^{4,5}$

During the course of the past 10 years, large portions of US manufacturing have moved to China, the US service sector has been moving to India, and the agricultural sector has been moving to Brazil and other Latin American countries. $^{5}$ In China, manufacturing jobs pay $\$ 5$ to $\$ 10$ per day compared to $\$ 160$ to $\$ 200$ per day in the United States. 5 Similar differences in wages apply to service sector jobs in India and agricultural sector jobs in Brazil. ${ }^{5}$ Under conditions of free but unbalanced trade, it is quite difficult for small and medium-sized American businesses to compete with those locating in developing countries. Generally the United States now has a trade advantage only for complex technologies involving the most current innovations. Large international companies formerly based in the United States are prospering because they have moved to other countries to take advantage of cheap labor and taxes and less environmental regulation. ${ }^{4-7}$

The other important part of the US trade deficits is that while Americans over-spend, their primary trading partners, particularly the Chinese, Japanese, and other Asian countries, over-save. ${ }^{5,6}$ American household debt is now at an all-time high of $120 \%$ of household income, and the annual savings rate is $-1 \%$ of income. ${ }^{3,6}$ In contrast, the Asians save $30 \%-40 \%$ of their income. Extreme 
over-consumption by the United States coupled with extreme under-consumption by its Asian trading partners are major factors in the enormous trade deficit of the United States.

\section{Financial Situation of Western Ranchers}

The financial outlook for western ranchers has changed somewhat since our analysis 12 years ago. ${ }^{2}$ At that time, low energy costs, declining per capita consumption of beef, several years of favorable precipitation, and increasing competition from Argentina and Australia were factors causing real cattle prices to be at historically low levels. Nevertheless, as a group, ranchers in New Mexico and other western states made a profit in nearly all years during the 1980s and early 1990s. Since 1994, extended drought has been an important factor depressing ranch profitability in New Mexico and several other states. Since 1996, cattle prices have been in an uptrend due to an increasing human population with rising affluence, increased per capita consumption of beef, depressed cattle numbers due to drought, and depressed beef production in Europe due to mad cow disease (bovine spongiform encephalopathy). In the period from 1992 to 2006, domestic beef consumption in the United States grew by $14 \%$ while beef exports from the United States increased by $85 \% .{ }^{8}$ However, after the December 2003 discovery of mad cow disease in a Washington state dairy cow, various countries banned some or all US beef and cattle products. In 2003, the United States had 18\% of the world beef market and was the third largest beef exporter behind Australia and Brazil. In 2004, the United States' share of the world's beef market plummeted to 3\%, whereas Brazil held $27 \%$ and Australia held 20\%.

Japan (37\%), followed by Korea (24\%), Mexico (20\%), and Canada (10\%) have been the largest importers of US beef. Japan substituted beef from other sources (primarily Australia and New Zealand) for beef it was importing from the United States prior to $2004 .{ }^{8}$ However, in mid-December 2005, Japan lifted its ban on beef imports from the United States. Through 2004 and 2005, US beef prices held up well despite the US beef ban in Japan and other countries. This is explained by lower US cow inventories due to drought in the Great Plains, steady US beef demand, and a 2003 ban on importation of beef and cattle from Canada into the United States

In 2007, it is expected that US beef exports will increase to $6 \%$ or more of the world market, compared to $3 \%$ in 2004. The United States is slowly regaining market share it lost from the "mad cow disease" scare in 2003 because Canada, Mexico, and Japan are again accepting US beef. Restrictions on cattle and beef imports from Canada in 2003 due to "mad cow disease" indicate that US cattle prices are more positively impacted by decreases in imports than reductions in exports. The United States is the largest importer of beef in the world. In recent years, imports have accounted for about $13 \%$ of total beef consumption in the
United States. ${ }^{8}$ Until the ban on Canadian beef in May, 2003, Canada was the primary source of beef imports into the United States. Historically, Canada has exported around $60 \%$ of its beef production with $80 \%-90 \%$ going to the US.

Range livestock production in the western United States does not operate apart from the world economy and globalization. There is increasing controversy over the free trade policies of the US government since the late 1980s. This is because of the escalating US trade deficit previously discussed and relocation of the US manufacturing base to China, service sector to India, and agricultural sector to Brazil. Various trading partners of the United States engage in policies of currency manipulation, subsidization, and less stringent environmental regulation that put US producers at a disadvantage. ${ }^{5,7}$ This applies to western cattle ranchers as well as many other types of businesses.

\section{Range Livestock Production and Peak Oil}

A new factor that could greatly affect United States agriculture, including range cattle operations, is "peak oil." There is credible but controversial evidence that world oil production might be nearing or at a peak and will start to decline within 3 to 15 years. ${ }^{9,10}$ At the same time, world demand for oil is rising about $1.6 \%$ per year. Once world oil production begins to decline, global agriculture could drastically change. ${ }^{9,11}$ This is because the big boosts in food production over the past 40 years from the "green revolution" depend heavily on fertilizer, herbicides, pesticides, and irrigation linked to fossil fuel (oil and natural gas) use. The cheap feed grains used in productions of chickens, pigs, and cattle could become a thing of the past. Under the future scenario predicted by Kunstler of severe world fossil fuel shortages, the United States could be forced to produce most of its own food using low-intensity agricultural practices of the nineteenth century. Range livestock production would again play a critical role in providing the nation with meat. Although the predictions of Kunstler seem both dire and extreme, some, but not all energy experts believe that world oil/natural gas shortages with 3 to 25 years are a possibility., ${ }^{9,12}$ The pessimists further point out that all of the alternative energy sources including biomass, coal, wind, nuclear power, and fuel cells presently have limitations as replacements for oil and natural gas. Our own analyses indicate that great uncertainty exists regarding world supplies of fossil fuels and the potential of alternative energy sources to replace them. Sustaining food production on US farmlands and rangelands is a rational hedge against the dark scenario prophesized by Kunstler.

Keep in mind, range livestock production involves 30\% to $80 \%$ lower energy inputs than present production systems depending on degree of fattening and amount of meat transport. High shipping costs in conjunction with dollar devaluation could make importation of meat from other countries infeasible. Meat and agricultural produce produced 
locally and regionally could become much cheaper than imported food.

Here we will comment about the quality of grassfattened beef. In the United States, grass-fattened beef is considered inferior to grain-finished beef in terms of tenderness and taste. This is largely due to lack of proper aging of grass-fattened beef. It takes $2-4$ weeks of aging to properly prepare grass-fattened beef for the table. We have eaten much properly aged grass-fattened beef that we considered superior in taste, tenderness, and healthiness to the corn-fed beef sold in the large US chain food stores and restaurants. Improved profit margins for ranchers and the decline of the large retail chain stores (Wal-Mart) due to the end of abundant cheap oil could make it profitable for ranchers to raise, properly age, and sell their beef in local markets. Some ranchers in New Mexico are already doing this.

\section{Finall Thoughts}

Generally, the public, the news media, and politicians project a continuation of the trend towards globalization now in progress. Improved communication, adoption of market economies, cheap energy, free trade, and massive trade deficits by the United States have all been factors favoring rapid globalization since 1990. Globalization has greatly altered the US economy from being primarily exportoriented to import-oriented. It has provided the US consumer with cheap manufactured goods and food shipped long distances at the expense of local industries and agriculture. Escalating trade deficits, consumer debt, and public debt in the United States have caused some economists to strongly question whether globalization as it is now practiced can continue. Key features of globalization are the need for cheap energy and never ending debt expansion by the United States. Because the United States is the world's largest economy and controls the world's money supply through the dollar, it has had the capability to consume more than it produced for the past 33 years. If world leaders should decide to end the dollar's role as the world's primary monetary unit, the United States could lose much of its cheap import capability and would again have to rely heavily on domestic production. A new emerging factor that could alter globalization is the possibility "peak oil." This controversial concern centers around a limit to the amount of oil that can be extracted due to declining world supply, coupled with increasing world demand. Rapid economic growth in China, India, Brazil, Russia, and other countries as well as increased demand in the United States is straining world oil supplies. Some energy experts express doubt that cheap, alternative energy sources can be easily developed and substituted for oil. ${ }^{9-12}$ If this proves true, then the trend toward globalization might be reversed. The United States might again be forced to rely on domestically produced goods and food. However, the production of these goods and food could be far more costly than in the age of cheap oil. Lower-input agricultural systems similar to those at the end of the nineteenth century might be the only alternative if there are no breakthroughs that provide cheap energy after peak oil. Under this scenario, rangeland livestock production would play a critical role in providing the nation with meat. Therefore, we consider it highly important to national security to conserve the nation's rangelands and sustain livestock production (ranching) on both public and private rangelands.

\section{References}

1. Holecheк, J. L. 2006. Changing western landscape, debt, and oil: a perspective. Rangelands 28:1-6.

2. Holechek, J. L., J. Hawkes, and T. D. Darden. 1994. Macroeconomics and cattle ranching. Rangelands 16:118-123.

3. Swanson, G. J. 2004. America the broke. New York, NY: Doubleday Books. 206 p.

4. Duncan, R. 2005. The dollar crisis: Causes, consequences, cures. Hoboken, NJ: John Wiley \& Sons. 324 p.

5. Prestowitz, C. 2005. Three billion new capitalists. New York, NY: Basic Books. 321 p.

6. Bonner, B., And A. Wiggin. 2006. Empire of debt: The rise of an epic financial crisis. Hoboken, NJ: John Wiley \& Sons. $370 \mathrm{p}$.

7. Kynge, J. 2006. China shakes the world. New York, NY: Houghton Mifflin Company. 270 p.

8. Hanrahan, C. B., and G. S. Becker. 2006. Mad cow disease and U.S. beef trade. Congressional Research Service. Washington, DC: The Library of Congress. 5 p.

9. Heinberg, R. 2005. The party's over. 2nd ed. Gabriola Island, Canada: New Society Publishers. 306 p.

10. Simmons, M. 2005. Twilight in the desert: The coming Saudi oil shock and the world economy. Hoboken, NJ: John Wiley \& Sons. 422 p.

11. Kunstler, J. K. 2005. The long emergency. New York, NY: Grave Press. 324 p.

12. Tertzakian, P. 2006. A thousand barrels a second. New York, NY: McGraw-Hill. 272 p.

Authors are Professor of Range Science, Department of Animal and Range Sciences, holechek@nmsu.edu (Holechek); and Assistant Professor, Department of Agricultural Economics and Business, New Mexico State University, Las Cruces, NM 88003 (Hawkes). This paper was supported by the New Mexico Agricultural Experiment Station and was part of project 1-5-27410. 